\title{
Clinical Significance of CD200 and CD56 in Patients with Acute Lymphoblastic Leukemia
}

\author{
Salah E. Aref ${ }^{1}$, Kadry A. EL-Bakry², Emad El-din Azmy ${ }^{3}$, Lobna S. Ibrahim² \\ ${ }^{1}$ Clinical pathology department, Faculty of Medicine, Mansoura University. \\ ${ }^{2}$ Zoology department, Faculty of science, Damietta University. \\ ${ }^{3}$ Internal medicine department, Faculty of Medicine, Mansoura University.
}

Received: 3 Sept. 2016 /Accepted: 17 November 2016

*Corresponding author: lobnaahmed371@gmail.com

\begin{abstract}
To analyze CD200 and CD56 expression by flow cytometry in acute lymphoblastic leukemia patients and whether their overexpression had prognostic impact individually and in combination with each other. Seventy newly diagnosed patients were assessed, of whom 27 were adult ALL and 43 pediatric ALL. Forty seven of 70 cases (67\%) showed CD200 expression, and 7 cases (10\%) showed CD56 expression but only 3 cases (4.3\%) had expression for CD200+ and CD56+. Significance differences were found between CD200\& CD56 expression in whole ALL patients group compared to control group $(\mathrm{P}<0.0001$ and $\mathrm{P}<0.001$ respectively). Splenomegaly and lower hemoglobin and platelet were more frequently observed in CD200+ patients whose also associated with significant increase of myeloid marker CD34 frequency. There were significant differences in overall survival $(\mathrm{P}=0.042, \mathrm{P}=0.006)$ and disease-free survival $(\mathrm{P}=0.005, \mathrm{P}=0.002)$ between the CD200+ and CD200- patients in total ALL patients and adult ALL. Whereas, in pediatric ALL OS of CD200+ patients $35.7 \%$ compared to $86.2 \%$ in CD200-, $\mathrm{P}=0.032$ but DFS showed nonsignificant difference $(\mathrm{P}=0.099)$. On the other hand, $\mathrm{CD} 56+$ patients had lower complete remission rate $(14.3 \%$ vs. $63.5 \%, \mathrm{P}=0.018)$. $\mathrm{CD} 56+$ had significant influence on overall than those of CD56(28.6\% with mean 4.7 months vs. $41.1 \%$ with mean=11.8 months, $\mathrm{P}=0.003$ ) and disease free survival $(40 \%$ with mean $=6.26$ months vs. $54.9 \%$ with mean $=14.16, \mathrm{P}=0.006)$. In respect to combination of two CDs positive had very inferior OS and DFS (mean $=0.533$ month and 0.150 month). In addition to, increased frequency of CD34 was associated with CD200+, CD56+ patients.
\end{abstract}

Keywords: Lymphoblastic Leukemia, Gene Expression, Immuno-phenotyping

\section{Introduction}

Acute lymphoblastic leukemia is a serious type of malignancies that originates from the development and differentiation of the early version of lymphocytes in the bone marrow and has an Acute lymphoblastic leukemia is a serious type of malignancies that originates from the development and differentiation of the early version of lymphocytes in the bone marrow and has an 
annual increase of $1.4 \%$, in the incidence worldwide. The highest incidence was observed in the ages between 1-4 years with a marginal predominance of males over female (Timothy et al., 2016).

CD200 is a trans-membrane cell surface glycoprotein encoded by a gene residing at chromosome 3q12.(McCaughan et al., 1987). It is belonging to the type-I immunoglobulin superfamily and also known as MOX-2" (Wright et al., 2001). It is related to the B7 family of costimulatory receptors, with two extracellular domains, a single transmembrane region, and cytoplasmic tail without signal motif (Barclay et al., 2002).

CD200-CD200R interactions have a role in modulated cell mediated immunity with significant lymphocytic involvement (Walker et al., 2013), regulation of myeloid differentiation and or activation, fetal loss, transplant rejection (Gorczynski, 2001) and autoimmunity (Gorczynski et al., 2002). However, CD200 has a central role in immune tolerance that protect stem cells and other critical tissues from immune damage (Gorczynski et al., 2001).CD200 can induce neuritogenesis and promote neuronal survival in primary neurons through activation of the fibroblast growth factor receptor (FGFR) (Pankratova et al., 2016).

CD200 with its receptor CD200R delivers an inhibitory signal to the target cell in most circumstances (Jenmalm et al., 2006) and imparts an immunosuppressive signal leading to inhibition of macrophage function (Hoek et al., 2000), induction of regulatory $\mathrm{T}$ cells (Gorczynski et al., 2005), switching of cytokine profiles from Th1 to Th2 and inhibition of tumor-specific T-cell immunity(Coles et al., 2011) . In leukemia and other malignancies CD200(OX2) act as an immunosuppressive surface protein its expression associated with inhibition of antitumor $\mathrm{T}$ cell responses and decreased overall survival of patients (Shannon K Oda1 2016). CD200 suppresses the immune system's response to vaccines, and that blocking CD200 could improve the efficacy of cancer immunotherapy (Xiong et al., 2016).
CD200 expression on human malignancies is associated with tumor progression, and predict worse overall survival for various forms of leukemia patients (Rygiel et al., 2012). AML patients with CD200 high were shown to have inferior survival compared with those CD200low and increased risk of relapse (Atfy M, 2015).

CD56 is a neural- cell adhesion molecule (N-CAM) that known as a marker of natural killer cells (NK) (Farag et al., 2003). It expressed on a subset of normal $T$ cells and occasionally on blasts in T-cell acute lymphoblastic leukemia especially a subgroup of T-ALL patients who did not respond to therapy (Dalmazzo et al., 2009). NK- cells are phenotypically and functionally very similar to $\mathrm{T}$ - cells (cytotoxic T-cells) as it arise from T/NK bipotential common progenitor (Shibuya $\boldsymbol{e t}$ al., 1995).

High incidence of CNS disease was found in adult ALL patients who expressed CD56 (Ravandi et al., 2002a) . The expression of CD56 has been shown to be of prognostic relevance in certain hematologic malignancies as well as it was found an inferior survival in small series of $\mathrm{CD}^{+}{ }^{+}$T-ALL (Montero et al., 2003). CD56 expression should be regarded as an independent risk factor for ALL with CNS involvement in adults (Hu et al., 2016). Also aberrant co-expression of the NK cell marker CD56, CD117 and CD33 and the stem cell marker CD34 in a patient with T-cell ALL appears to be associated with an unfavorable outcome (Eren et al., 2016).

The aim of the present study is the estimation of CD200 and/or CD56 expression in acute lymphoblastic leukemia patients and their prognostic impact.

\section{Materials and Methods}

\section{Patients:}

Pretreatment bone marrow and peripheral blood specimens were obtained from 70 patients (2-52 years of age) at Mansoura Oncology Center, Mansoura University, Egypt. Lymphoblastic leukemia cases were diagnosed according to the French-American- British criteria and immunophenotypic analysis. Patients 
with newly diagnosed acute lymphoblastic leukemia were included in this study subjected to these criteria; laboratory investigations, immune-phenotypic and clinical examination of patients. Complete remission $(\mathrm{CR})$ was considered when bone marrow blast cell counts were $<5 \%$.

\section{Immuno-phenotyping}

Immuno-phenotypic analyses for ALL patients were performed according to standard techniques on a FACS can flow cytometer. In order to perform IPT of the blasts a broad panel of fluorochrome conjugated monoclonal antibodies (mAbs) were used that included : anti- CD3(PEHIT3a), CD4(FITC-RPA-T4), CD5(FITCUCHT2), CD7(FITC-8H8.1), CD8(APCRPA-T8),CD10(PE-

HI10a),CD13(PECY5-Immu103-44), CD14(PE-M5E2),CD19(PE-HIB19), CD20 (PE-2H7 ), CD22 (PE-HIB22), CD33(FITC-HiM3-4), CD34(PE-581), HLADR(PE-Immu-357) and TDT(FITCE17-1519). In addition, CD200 (PE- MRC OX-104) and CD56 (FITC- NCAM16.2) mAbs were also used. Samples were stained with monoclonal antibodies against cell surface markers as described before using stain - lyse - wash then direct immunofluorescence technique was done (Porwit et al., 2015). Briefly, 100 $\mu 1$ of BM or PB sample were added to $20 \mu \mathrm{l}$ of $\mathrm{mAb}$ of each $\mathrm{CD}$, then incubated for $15 \mathrm{~min}$ at room temperature. Cell suspensions were washed with phosphate buffer saline (PBS) and $2 \mathrm{ml}$ of 1x BD FACS Lysing solution were added. Vortex and incubate $10 \mathrm{~min}$. at room temperature and then centrifuged for $5 \mathrm{~min}$ at $350 \mathrm{rpm}$. Cells were washed twice with PBS, the cell pellet was re-suspended in $500 \mu \mathrm{l} \mathrm{PBS}$. Then, the sample became ready for acquisition and analysis by flow cytometry. When expression of a marker on the lymphatic blasts $\geq 20$ defined as positive.

\section{$B C R-A B L$ detection}

Samples were tested for $t(9 ; 22)$ by using real-time quantitative PCR. The assay involves a duplicate real-time amplification reaction for the target and a duplicate real-time amplification reaction for the control. There are two main parts in the test, the amplification reaction is carried out specific for a region of the mRNA of P210, while in the second step, an amplification reaction is carried out specific for a region of the mRNA of ABL using the cDNA produced by the reverse transcription reaction of the RNA extracted from the test samples. System standardization was carried out on Applied Biosystems ABI PRISMTM 7000 series instruments.

\section{Statistical analysis}

All statistical analyses were performed using the SPSS software package and Graph Pad Prism (Graph Pad Software, Inc; San Diego, CA) to analyze P values. Data were statistically described in terms of mean $\pm \mathrm{SE}$, mean $\pm \mathrm{SD}$ and mean with range. Overall survival was calculated from the date of first diagnosis to death from any cause. Whereas remission duration was calculated from the time of achievement of CR to time of relapse or death in CR. A probability value ( $p$ value) less than 0.05 was considered statistically significant.

\section{RESULTS}

\section{Patients characteristics}

The patients had a wide age range (2-56 years; mean 14.3). The majority $61.4 \%$, were children younger than 18 years with 7.8 mean age and about $38.6 \%$, were adult with mean age 32.7 year (table, 1 ).

\section{Analysis of CD200 expression}

ALL Patients with CD200- expression were significantly associated with male gender. CD $200^{+}$Patients were significantly associated with Splenomegaly. Otherwise, no significant associations were found between demographic or clinical data according to CD200 positivity when total ALL patients reclassified into pediatric and adult all patients ( table 1).

$\mathrm{CD}_{200}{ }^{+}$all patients presented with lower hemoglobin and platelet count compared to those with CD200 - Whereas, CD200 positivity in adult ALL patients had not influence in laboratory data (table 2). 
Table (1). Pre-treatment characteristics according to CD200 positivity in total ALL patients.

\begin{tabular}{c|c|c|c|c|c} 
& \multicolumn{4}{|c|}{ Total ALL $(\mathrm{n}=70)$} & \\
& \multicolumn{2}{|c|}{$\mathrm{CD}^{-} 200^{-}(\mathrm{N}=23)$} & \multicolumn{2}{c|}{$\mathrm{CD} 200^{+}(\mathrm{N}=47)$} & $P$ \\
Age (years) & $\mathrm{N}$ & $\%$ & $\mathrm{~N}$ & $\%$ & \\
Males & 15.3 & $2-56$ & 13.5 & $2-52$ & 0.862 \\
Females & 18 & 75.0 & 22 & 47.8 & $0.029^{* *}$ \\
Pallor & 6 & 25.0 & 24 & 52.2 & 0.863 \\
Fever & 12 & 50.0 & 24 & 52.2 & 0.400 \\
Weight loss & 16 & 66.7 & 35 & 76.1 & 0.429 \\
Pain & 9 & 37.5 & 13 & 28.3 & 0.729 \\
Bleeding tendency & 12 & 50.0 & 21 & 45.7 & 0.373 \\
Bone ache & 4 & 16.7 & 12 & 13.0 & 0.493 \\
Splenomegaly & 5 & 20.8 & 6 & 86.9 & $0.031^{*}$ \\
Hepatomegaly & 15 & 62.5 & 40 & 78.3 & 0.520 \\
Lymphadenopathy & 21 & 87.5 & 36 & 71.7 & 0.500 \\
\hline
\end{tabular}

$\mathrm{N} \& \%$, number of pre-treatment ALL patients with each clinical data and their ratio.

$*$, indicating significant difference.

**, highly significant.

Table (2). laboratory data according to CD200 positivity in total ALL patients.

\begin{tabular}{|c|c|c|c|}
\hline & \multicolumn{2}{|c|}{ Total ALL(n=70) } & \multirow[b]{2}{*}{$\boldsymbol{P}$} \\
\hline & $\begin{array}{l}\text { CD200- }^{-} \\
(\mathbf{n}=23) \\
\text { Mean }\end{array}$ & $\begin{array}{c}\text { CD200 }^{+} \\
(\mathbf{n}=47) \\
\text { Mean }\end{array}$ & \\
\hline $\begin{array}{c}\text { Total leucocytic } \\
\text { count } \\
\left(\mathrm{X} 10^{9} / \mathrm{L}\right)\end{array}$ & $\begin{array}{c}23.3 \\
(1.5-520)\end{array}$ & $\begin{array}{c}26.6 \\
(1.6-374.8)\end{array}$ & 0.839 \\
\hline $\begin{array}{l}\text { Hemoglobin } \\
\text { concentration } \\
(\mathrm{g} / \mathrm{dL})\end{array}$ & $\begin{array}{c}8.1 \\
(3.8-12.2)\end{array}$ & $\begin{array}{c}6.9 \\
(3-13.8)\end{array}$ & $0.046^{*}$ \\
\hline $\begin{array}{l}\text { Platelet count } \\
\left(\mathrm{X} 10^{9} / \mathrm{L}\right)\end{array}$ & $\begin{array}{c}92.3 \\
(7-582)\end{array}$ & $\begin{array}{c}49.9 \\
(5-186)\end{array}$ & $0.027 * *$ \\
\hline $\begin{array}{c}\text { Peripheral } \\
\text { blasts } \\
(\%)\end{array}$ & $\begin{array}{c}45 \\
(0-88)\end{array}$ & $\begin{array}{c}85 \\
(70-95)\end{array}$ & 0.053 \\
\hline $\begin{array}{c}\text { Marrow blasts } \\
(\%)\end{array}$ & $\begin{array}{c}88.5 \\
(62-96)\end{array}$ & $\begin{array}{c}90 \\
(75-98)\end{array}$ & 0.837 \\
\hline $\begin{array}{l}\text { Albumin } \\
(\mathrm{g} / \mathrm{dL})\end{array}$ & $\begin{array}{c}4.095 \\
(3.1-5.0)\end{array}$ & $\begin{array}{c}4.1 \\
(1.8-5.5)\end{array}$ & 0.931 \\
\hline $\begin{array}{l}\text { Bilirubin } \\
(\mathrm{mg} / \mathrm{dL})\end{array}$ & $\begin{array}{c}0.8 \\
(0.4-2.0)\end{array}$ & $\begin{array}{c}0.7 \\
(0.2-4.0)\end{array}$ & 0.804 \\
\hline $\begin{array}{l}\text { ALT } \\
\text { (U/L) }\end{array}$ & $\begin{array}{l}18.35 \\
(7-130)\end{array}$ & $\begin{array}{c}23.85 \\
(8-168)\end{array}$ & 0.552 \\
\hline $\begin{array}{l}\text { AST } \\
\text { (U/L) }\end{array}$ & $\begin{array}{c}38.5 \\
(19-211)\end{array}$ & $\begin{array}{c}34 \\
(14-124)\end{array}$ & 0.237 \\
\hline $\begin{array}{l}\text { Creatinine } \\
(\mathrm{mg} / \mathrm{dL})\end{array}$ & $\begin{array}{c}0.97 \\
(0.5-3.9)\end{array}$ & $\begin{array}{c}0.8 \\
(0.3-8.2)\end{array}$ & 0.240 \\
\hline $\begin{array}{l}\text { Uric acid } \\
(\mathrm{mg} / \mathrm{dL})\end{array}$ & $\begin{array}{c}6.37 \\
(1.8-33.2)\end{array}$ & $\begin{array}{c}4.925 \\
(1.3-14.6)\end{array}$ & 0.066 \\
\hline $\begin{array}{l}\text { LDH } \\
\text { (U/L) }\end{array}$ & $\begin{array}{c}1105.85 \\
(176- \\
9373)\end{array}$ & $\begin{array}{c}616.5 \\
(131-3997)\end{array}$ & 0.080 \\
\hline $\begin{array}{l}\text { Calcium } \\
(\mathrm{mg} / \mathrm{dL})\end{array}$ & $\begin{array}{c}8.75 \\
(5.9-12.1)\end{array}$ & $\begin{array}{c}8.4 \\
(6.1-11.5)\end{array}$ & 0.216 \\
\hline
\end{tabular}

Cases were assigned to the $\mathrm{CD}^{-00}(<20)$ and $\mathrm{CD} 200+(>20)$ subgroups based on independent assessment of CD200 expression by flow cytometry. Data between arches represent range.

\section{Analysis of CD56 expression}

There were no significant differences in both the $\mathrm{CD}^{+} 6^{+}$and $\mathrm{D}^{-} 6^{-}$subgroups concerning sex and clinical presentation.
There were high proportion of patients in both groups presented with splenomegaly, lymphadenopathy and hepatomegaly. However $\mathrm{CD}^{+} 6^{+}$ALL presented with higher platelet counts compared to the $\mathrm{CD}^{-} 6^{-}$patients . This difference was statistically significant in both total ALL patients and pediatric ALL patients $(\mathrm{P}=$ $0.024, \mathrm{P}=0.019$ ).

Table (3). Laboratory data according to CD56 positivity in total ALL group.

\begin{tabular}{|c|c|c|c|}
\hline & $\begin{array}{l}\text { CD56-ve }^{-v} \\
(n=63) \\
\text { Mean }\end{array}$ & $\begin{array}{l}\text { CD56 +ve } \\
(n=7) \\
\text { Mean }\end{array}$ & $P$ \\
\hline $\begin{array}{l}\text { Total leucocytic } \\
\text { count } \\
\left(\mathrm{X} 10^{9} / \mathrm{L}\right)\end{array}$ & $\begin{array}{l}26.6 \\
(1.5-520)\end{array}$ & $\begin{array}{l}18.3 \\
(1.7-39.1)\end{array}$ & 0.236 \\
\hline $\begin{array}{l}\text { Hemoglobin } \\
\text { concentration } \\
(\mathrm{g} / \mathrm{dL})\end{array}$ & $\begin{array}{l}7.17 \\
(3.0-13.8)\end{array}$ & $\begin{array}{l}7.7 \\
6.8-10.6)(\end{array}$ & 0.129 \\
\hline $\begin{array}{l}\text { Platelet count } \\
\left(\mathrm{X} 10^{9} / \mathrm{L}\right)\end{array}$ & $\begin{array}{l}51.5 \\
5-582)(\end{array}$ & $\begin{array}{l}140 \\
26-397)(\end{array}$ & $0.024 *$ \\
\hline $\begin{array}{l}\text { Peripheral blasts } \\
(\%)\end{array}$ & $\begin{array}{l}90 \\
62-98)(\end{array}$ & $\begin{array}{l}90 \\
80-90)(\end{array}$ & 0.214 \\
\hline $\begin{array}{l}\text { Marrow blasts } \\
(\%)\end{array}$ & $\begin{array}{l}70 \\
0-98)(\end{array}$ & $\begin{array}{l}80 \\
55-93)(\end{array}$ & 0.201 \\
\hline $\begin{array}{l}\text { Albumin } \\
(\mathrm{g} / \mathrm{dL})\end{array}$ & $\begin{array}{l}4.1 \\
2.8-5.5)(\end{array}$ & $\begin{array}{l}3.9 \\
(1.8-4.1)\end{array}$ & 0.076 \\
\hline $\begin{array}{l}\text { Bilirubin } \\
(\mathrm{mg} / \mathrm{dL})\end{array}$ & $\begin{array}{l}0.8 \\
0.2-4.0)(\end{array}$ & $\begin{array}{l}0.7 \\
0.4-1.7)(\end{array}$ & 0.784 \\
\hline $\begin{array}{l}\text { ALT } \\
(\mathrm{U} / \mathrm{L})\end{array}$ & $\begin{array}{l}20 \\
7-168)(\end{array}$ & 19 & 0.487 \\
\hline $\begin{array}{l}\mathrm{AST} \\
(\mathrm{U} / \mathrm{L})\end{array}$ & $\begin{array}{l}37 \\
14-211)(\end{array}$ & $\begin{array}{l}34 \\
(15-126)\end{array}$ & 0.914 \\
\hline $\begin{array}{l}\text { Creatinine } \\
(\mathrm{mg} / \mathrm{dL})\end{array}$ & $\begin{array}{l}0.85 \\
0.3-8.2)(\end{array}$ & $\begin{array}{l}0.6 \\
0.5-1.0)(\end{array}$ & 0.098 \\
\hline $\begin{array}{l}\text { Uric acid } \\
(\mathrm{mg} / \mathrm{dL})\end{array}$ & $\begin{array}{l}5.4 \\
1.3-33.2)(\end{array}$ & $\begin{array}{l}3.47 \\
(1.8-5.9)\end{array}$ & 0.094 \\
\hline $\begin{array}{l}\mathrm{LDH} \\
(\mathrm{U} / \mathrm{L})\end{array}$ & $\begin{array}{l}714.9 \\
(190-9373)\end{array}$ & $\begin{array}{l}461 \\
(131-7414)\end{array}$ & 0.564 \\
\hline $\begin{array}{l}\text { Calcium } \\
(\mathrm{mg} / \mathrm{dL})\end{array}$ & $\begin{array}{l}8.55 \\
5.9-11.5)(\end{array}$ & $\begin{array}{l}8.7 \\
(7.9-12.1)\end{array}$ & 0.473 \\
\hline
\end{tabular}


Expression of CD200 and CD56:

Total ALL patients according to combination of CD200 and CD56 positivity were reclassified into four groups: ALL Patients with CD200+ ${ }^{+} D 56^{+}$ , $\mathrm{CD} 200^{+} \mathrm{CD}^{-} 6^{-}, \mathrm{CD} 200^{-} \mathrm{CD}^{+} 6^{+}$and CD200- CD56: As in table(4), although, statically no significant associations were found between demographic or clinical data according to CD200, CD56 positivity in total ALL patients , CD200 ${ }^{+} \mathrm{CD}^{+} 6^{+}$
Patients were associated with more pain and increased frequency of Splenomegaly. Whereas, CD200- ${ }^{-} D 56^{+}$patients had male gender prevalence with hepatomegaly.

$\mathrm{CD} 200^{+} \mathrm{CD}^{2} 6^{+}$patients had the lowest platelet count (53; range $26-140$ ) and significant lower LDH activity. Whereas patients with $\mathrm{CD}^{200}{ }^{-} \mathrm{CD}^{-} 6^{+}$were characterized by increased platelet count at diagnosis and higher LDH activity compared to other studies groups.

Table (4). Demographic and clinical data according to CD200, CD56 positivity in total ALL patients.

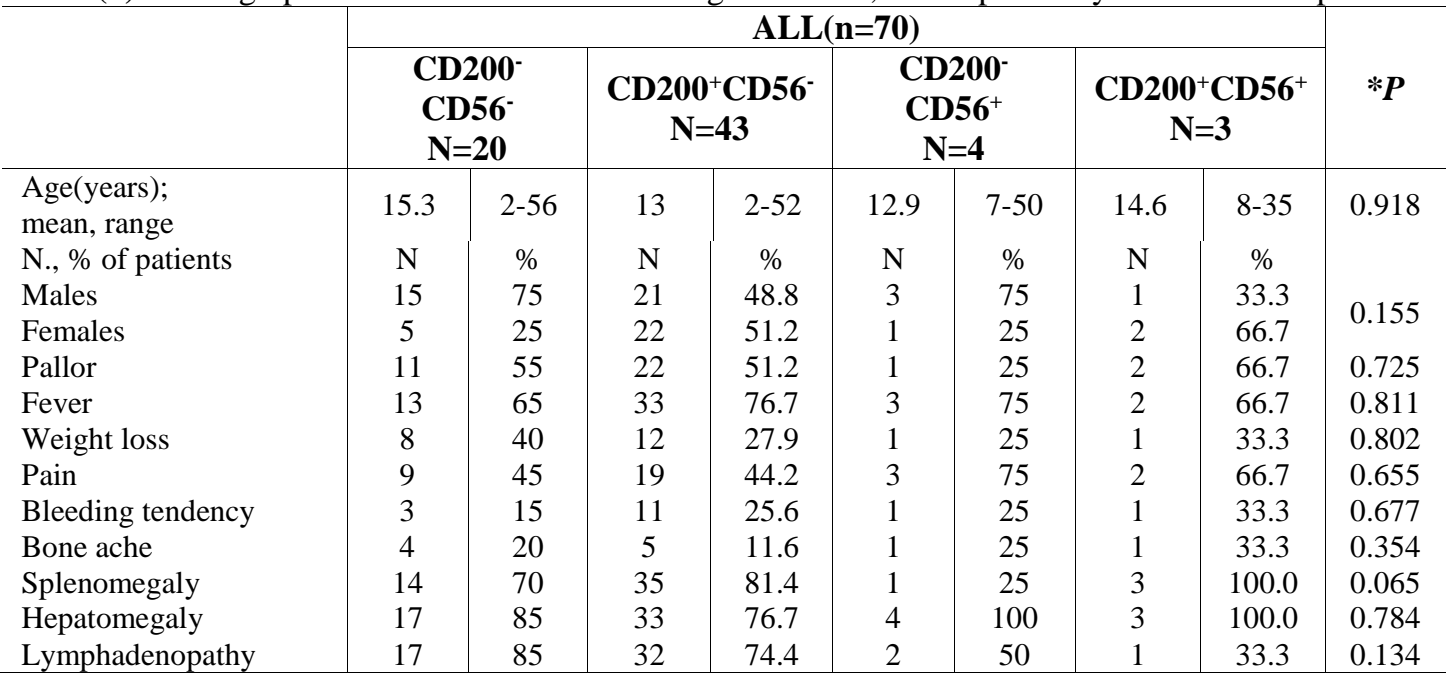

* P value was determined using one way ANOVA test.

Immuno-phenotype

Expression of CD200 was evaluated in 70 pre-treatment acute lymphoblastic leukemia patients. A total of $67 \%$ of all patients were positive for CD200 but only $10 \%$ positive for CD56 as well as in relation to age $65 \%$ of pediatric ALL patients were positive for CD200 but about $11.6 \%$ positive for CD56. However in adult ALL patients about $70 \%$ were positive for CD200 and only $7.4 \%$ positive for CD56 (figure,1). Only 3 out of 70 ALL patients in our study have been found positive for both CDs. CD200 positively was observed in $72.5 \%$ of B - ALL patients that also $7.8 \%$ positive for CD56 whereas, $60 \%$ and $13.3 \%$ of T-ALL patients were positive for CD200 and CD56 respectively figure(2,3). These observations led us to assess the expression of CD200 in relation to FAB classification that summarized in table (5) CD200 more frequency positive in patients with L2 $88.1 \%$ but only $2.4 \%$ CD56+, as well as $47.6 \%$ of $\mathrm{L} 1$ positive for CD200 and 19\% for CD56 . Although none of L3 express CD200 about $28.6 \%$ positive for CD56.

The immune-phenotypic features were evaluated in all the ALL Patients. Both groups show similar finding, except for CD34+ that had significantly high frequency of positive expression in CD200+.

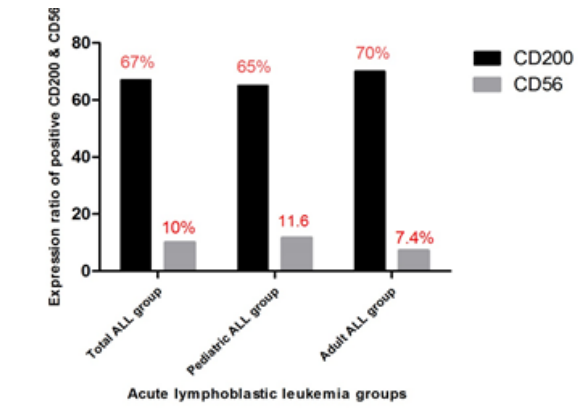

Fig(1). Expression ratio of CD200 \& CD56 positive in acute lymphoblastic leukemia groups. 


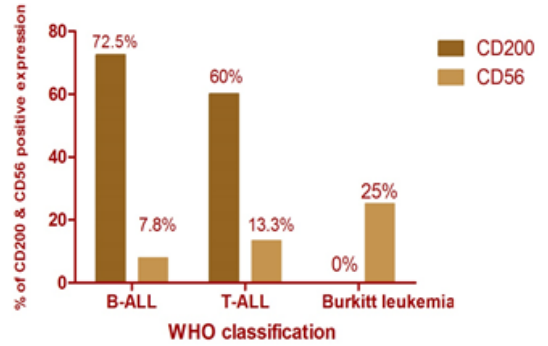

Fig (2). Ratio of expression of CD200 \& CD56 positive |regarding WHO classification of ALL patients.
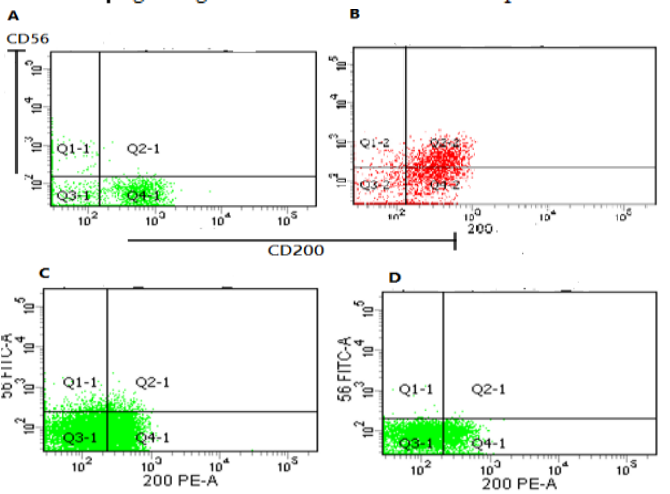

Fig. 3 . Expression of CD200and CD56 in BALL. (A)B-ALL patient with CD200 positive and CD56 negative. Whereas, ( B )represent BALL patients with two positive CDs $\left(\mathrm{CD} 200^{+}\right.$, $\mathrm{CD}^{+} 6^{+}$. Expression of CD200and CD56 in TALL. (C) represent T-ALL patients with high positive CD200 and low positive CD56. Whereas, (D) T-ALL patient with CD200 positive and CD56 negative.

Table (5). Expression of CD200 in FAB classification of total Acute lymphoblastic leukemia patients group.

\begin{tabular}{l|l|l|l}
\hline FAB & $\begin{array}{c}\text { No. of } \\
\text { cases }\end{array}$ & $\begin{array}{c}\text { No., \% with } \\
\text { CD200 } \\
\text { expression }\end{array}$ & \multicolumn{1}{|c}{$\begin{array}{c}\text { No., \% } \\
\text { with CD56 }\end{array}$} \\
\hline L1 & 21 & $10(47.6 \%)$ & $4(19 \%)$ \\
L2 & 42 & $37(88.1 \%)$ & $1(2.4 \%)$ \\
L3 & 7 & $0(0 \%)$ & $2(28.6 \%)$ \\
\hline
\end{tabular}

\section{Expression of CD200 and CD56 in relation to PCR - APL gene translocation}

There are six patients out of seventy have Philadelphia $t(9 ; 22)$ positive and $83 \%$ of them are CD200 positive but none of them express CD56.In our study only one pediatric case is Philadelphia $t(9 ; 22)$ positive which also CD200 positive but the other four positive CD200 cases from adult ALL group, fig(5).
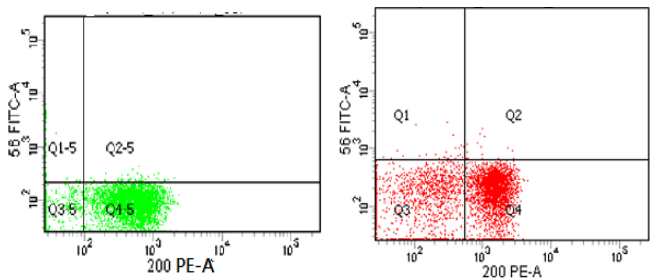

Fig 5. Expression of CD200and CD56 in Philadelphia $\mathrm{t}(9 ; 22)$ positive ALL. The patients positive for CD200 but negative for CD56.

\section{Treatment results}

Expression of CD200 had a significant adverse effect in clinical outcome and survival in ALL patients (figure,6) . CR rates did not differ in CD200 ${ }^{+}$ALL patients compared with CD200- ALL (54.2 v 60.9 ; 53.3 v 60.7 and 55.6 v 61.1 ) in total ALL patients, pediatric patients and adult patients respectively.

After a median follow- up of 25 months we find a significant influence of CD200 expression on overall survival (OAS). The cumulative OS \% for CD200- groups compared to $\mathrm{CD} 200^{+}$groups were $(62.3 \mathrm{vs}$ $28.7 ; 86.2$ vs 35.7 and77.8 vs 35.7 ) in total ALL patients, pediatric patients and adult patients, as well as the cumulative DFS \% were (77.4 vs 34.7 and 75 vs 10.9 ) in all patients and adult patients but in pediatric ALL patients CD200 did not effect in cumulative DFS \% (87.5 vs 49.5, $P=0.099$ ).

On the other hand, significantly less patients with $\mathrm{CD}^{2} 6^{+}$expression achieved complete remission compared to CD56- in total patients .However in pediatric CR rates did not differ regarding CD56. CD56 ${ }^{+}$ patients had an inferior survival compared to those with CD56- (41.1\% vs 28.6 and 50.1 vs 20 ) and shorter DFS ( 54.9 vs $39 \%$ and 65.7 vs $25 \%$ ).
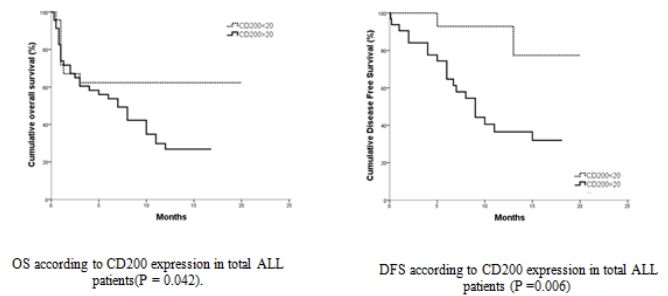

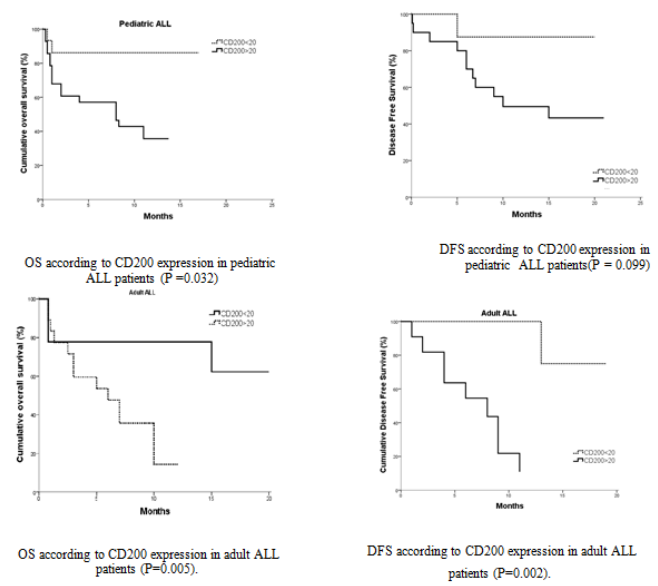

Fig. 6. OS and DFS in ALL patients group (total patient, pediatric ALL, adult ALL)

Results of follow up of responders after induction chemotherapy are summarized in table (6). All of patients with CD200 ${ }^{+}$and $\mathrm{CD}^{2} 6^{+}$cannot respond to therapy, survive and in terms of death had significant differences in induction death or in CR. As well as, the shorter OS and DFS were found in $\mathrm{CD} 200^{+} \mathrm{CD}^{2} 6^{+}$but the highest OS and DFS achieved by CD200- CD56-, $P<0.001$ (figure 7,8 ).

Table (6). Clinical outcome and OS according to CD200, CD56 positivity in total ALL patients.

\begin{tabular}{|c|c|c|c|c|c|c|c|c|c|}
\hline & \multicolumn{8}{|c|}{$\operatorname{ALL}(n=70)$} & \multirow{3}{*}{$P$} \\
\hline & \multicolumn{2}{|c|}{$\begin{array}{c}\text { CD200- CD56- } \\
\qquad \mathrm{N}=20\end{array}$} & \multicolumn{2}{|c|}{$\begin{array}{c}\text { CD200+CD56- } \\
\qquad \begin{array}{l}\mathrm{N}=43\end{array}\end{array}$} & \multicolumn{2}{|c|}{$\begin{array}{c}\text { CD200- CD56+ } \\
\mathrm{N}=4\end{array}$} & \multicolumn{2}{|c|}{$\begin{array}{c}\text { CD200+ } \\
\text { CD56+ } \\
\mathrm{N}=3\end{array}$} & \\
\hline & $\mathrm{N}$ & $\%$ & $\mathrm{~N}$ & $\%$ & $\mathrm{~N}$ & $\%$ & $\mathrm{~N}$ & $\%$ & \\
\hline CR & 12 & 60 & 28 & 65.1 & 1 & 25 & 0 & 0 & 0.074 \\
\hline PR & 1 & 5 & 4 & 9.3 & 1 & 25 & 0 & 0 & 0.557 \\
\hline $\mathrm{RD}$ & 2 & 10 & 5 & 11.6 & 0 & 0 & 0 & 0 & 1 \\
\hline ID & 4 & 20 & 7 & 16.3 & 1 & 25 & 2 & 66.7 & 0.170 \\
\hline Relapse & 2 & 10 & 10 & 23.3 & 2 & 50 & 0 & 0 & 0.268 \\
\hline Total death & 2 & 10 & 31 & 72.1 & 3 & 75 & 3 & 100 & $<0.001 *$ \\
\hline $\begin{array}{l}\text { 1year cumulative } \\
\text { OS }(\%)\end{array}$ & \multicolumn{2}{|c|}{90} & \multicolumn{2}{|c|}{27.1} & \multicolumn{2}{|c|}{50} & \multicolumn{2}{|c|}{0} & \\
\hline Mean (months) & \multirow{2}{*}{\multicolumn{2}{|c|}{$\begin{array}{l}18.080 \\
15.556-0.604\end{array}$}} & \multirow{2}{*}{\multicolumn{2}{|c|}{9.431}} & \multicolumn{2}{|c|}{7.875} & \multirow{2}{*}{\multicolumn{2}{|c|}{$\begin{array}{l}0.533 \\
0.249-0.818\end{array}$}} & $<0.001 *$ \\
\hline CI $95 \%$ & & & & & $0.1-16$ & & & & \\
\hline $\begin{array}{l}1 \text { year cumulative } \\
\text { DFS }(\%)\end{array}$ & \multicolumn{2}{|l|}{100} & \multicolumn{2}{|c|}{38.9} & \multicolumn{2}{|c|}{66.7} & \multicolumn{2}{|c|}{0} & \\
\hline Mean (months) & \multirow{2}{*}{\multicolumn{2}{|c|}{$\begin{array}{l}11.315 \\
9.254-12.651\end{array}$}} & \multirow{2}{*}{\multicolumn{2}{|c|}{$\begin{array}{l}11.761 \\
9.054-14.469\end{array}$}} & \multirow{2}{*}{\multicolumn{2}{|c|}{$\begin{array}{l}10.333 \\
4.298-16.369\end{array}$}} & \multirow{2}{*}{\multicolumn{2}{|c|}{$\begin{array}{l}0.150 \\
0.052-0.248\end{array}$}} & $<0.001 *$ \\
\hline CI 95\% & & & & & & & & & \\
\hline
\end{tabular}

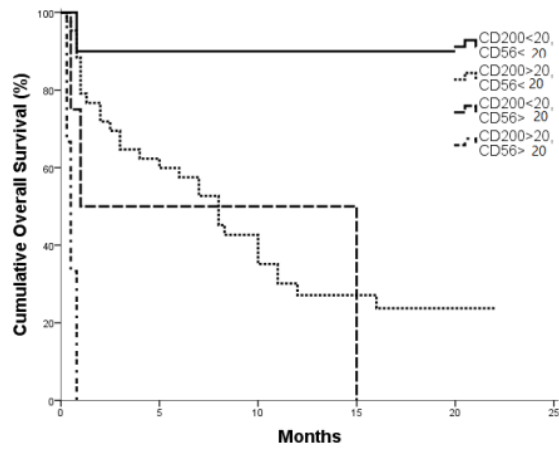

Figure (7). OS in total ALL patients according to CD200 and CD56 positivity

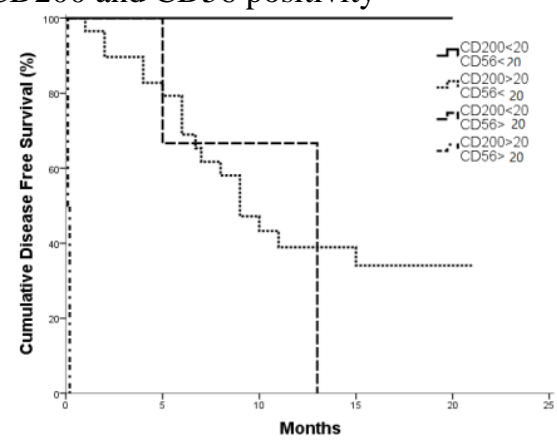

Figure (8). DFS in total ALL patients according to $\mathrm{CD} 200$ and CD56 positivity

\section{Discussion}

CD200 is a trans- membrane cell surface immunosuppressive glycoprotein which transduces inhibitory signals through interaction with CD200R (Barclay $\boldsymbol{e t}$ al., 2002). CD200 can be used as MRD markers in ALL patients and can also can serve as therapy targets (Adnan Awad $\boldsymbol{e t}$ al., 2016). CD200 is a key immunosuppressive molecule that has been implicated as a poor prognostic factor in multiple myeloma and acute myeloid leukemia (Cox et al., 2014).

We found in our study, the expression of CD200 was a quite common feature, was present in $67 \%$ of cases. These results are consistent with data reported by (Alapat et al., 2012) studies in which 19 of 25 cases were CD200 positive. These are 19 of 20 B-ALL (95\%) and 5 CD200- T-ALL. While our data listed( 37 of 51)B-ALL 
cases were positive for CD200 with ratio $72.5 \%$ and ( 9 of 15) T-ALL cases $(60 \%)$ were $\mathrm{CD}_{200^{+}}$which being in partial accordance with the reported data. Furthermore the higher prevalence of CD200 expression in 70\% of adult ALL patients in contrast to $65 \%$ of pediatric ALL patients.

However, Adnan Awad et al., (2016) reported that CD200 had widely expressed in their studies groups, $(80.3 \%)$ of B-ALL and can be used as MRD markers, serve as therapy targets in ALL patients. This ratio also was consistent with our results.

Our results show that CD200 positivity did not correlate with age, sex. Whereas, patients with CD200- expression ( under cut off) was significantly associated with male gender, no previous studies were report in this point. However, demographic or clinical data show that $\mathrm{CD} 200^{+}$expression were significantly associated with Splenomegaly, lower hemoglobin and platelet and did not influence in the clinical outcome .

Expression of CD200 determined by Cox et al.,(2014) study were found higher CD200 in bulk ALL cells compared to normal BM cells $(p=0.001)$ which agree with our study that found significant difference in CD200 in ALL patients compared to control cases $(\mathrm{P}=0.0001)$. Thus, our study may confirm utility of CD200 evaluation in distinguishing between leukemic lymphoblasts and normal hematogones that reported by (Alapat et al., 2012). The later study also found that CD200 is significantly over- or under expressed in $55 \%$ of CD34 ${ }^{+}$B-ALLs. Whereas, in this study, the myeloid marker CD34was significantly more frequently expressed in the CD200 ${ }^{+}$ALL group not regarding to $\mathrm{T}$ or $\mathrm{B}-\mathrm{ALL}$.

Investigation of CD200 positive leukemic cells to detect its influence on prognosis clear that high express of $\mathrm{CD} 200^{+}$is associated with bad prognosis or negative trend in OS and DFS both in total(whole) patients group ,although statistical significance was not reached for DFS in pediatric ALL patients which may be explains by more CD34+ frequently in CD200+ pediatric ALL patients as it reported before event-free survival was shorter for patients with CD34- leukemia (P $=.0014)$ (Borowitz et al., 1990). In contrast, CD34 expression is associated with features of poor prognosis in adult ALL(Thomas et al., 1995). Up to our knowledge, we are the first to find a statistically significant influences on OS and DFS regarding CD200 positivity.

NK cells usually kill target cells by engagement of specific, pair-wise combinations of receptors and induced secretion of tumor necrosis factor alpha (TNF-alpha) and interferon gamma (IFNgamma) (Bryceson et al., 2006). It is play an important role in tumor-cell clearance, particularly against leukemia cells which in turn may Reverse natural cytotoxicity receptors ( NCRs) phenotype after CR suggested so leukemia cells might be involved in NCR down-regulation (Fauriat et al., 2007). Furthermore CD56 expression has been determined in many hematologic malignancies with adverse influence. Expression of CD56 has been increased at relapse in T-ALL (Hashimoto et al., 2002).

CD56 expression in ALL is uncommon, our data demonstrated that the incidence of positive CD56 expression in the ALL patients was $10 \%$ for the whole group patients. Whereas, $\mathrm{CD}^{+} 6^{+}$was expressed in pediatric ALL patients with a percent $11.6 \%$ and $7.4 \%$ in adult ALL patients that similar to rates listed in many literature . CD56 is expressed differentially on adult T-ALL with ratio $13.9 \%$ by (Fischer et al., 2009). It was detected in $9 \%$ in ALL patients reported by Abdulateef $\boldsymbol{e t}$ al., (2014), 8\% Ravandi et al.,(2002), mildly lower frequency of CD56 expression were reported earlier; 3\% Paietta et al., (2001),5\% Seegmiller et al., (2009) and 2.2\% (Hussein et al., 2011).

However, study of Abdulateef et al., (2014) reported that one of three cases had $\mathrm{t}(9 ; 22)(\mathrm{BCR} / \mathrm{ABL})$ expressed CD56 which different with our results as none of 6 cases had $t(9 ; 22)$ expressed CD56. Whereas, five of these cases expressed CD200.

CD56+ ALL patients in all studies group exhibited few differences at diagnosis, namely higher platelet count. For other pretreatment characteristics no difference was found that comparable to others who reported lower white blood count, higher platelet levels and CNS involvement (Fischer et al., 2009).

CD56 expression has been shown to be have prognostic relevance in certain 
hematologic malignancies (Suzuki et al., 2003). An inferior survival of CD56+ TALL was reported by Montero et al., (2003), short survival were observed in patients who expressed CD56 (Montero et al ., 2007). Our results demonstrated that the OS was significantly lower in the group expressing CD56 in leukemic blasts, which was compatible with above data. We also found low complete remission and shorter DFS in CD56+ patients that agreement with low remission rates and biological aggressiveness in a significant proportion of acute leukemias were associated with CD56 expression at diagnosis (Elyamany et al., 2013). On the other hand, our results were not in agreement with Fischer et al., (2009) who reported that no significant influence on overall (48\% vs. 59\%) and disease free survival (67\% vs. $57 \%)$ at three years.

In this study we examined the presence of both CD200+, CD56+ and we investigated whether CD56 expression in ALL is a risk factor for shorter OS,DFS and a higher death rate during induction chemotherapy in patients. we found only 3 patients with CD200+,CD56+ and this aberrant CD200 and CD56 expression in ALL at diagnosis has been recognized to be a poor prognostic indicator and associated with biological aggressiveness. However, CD56 expression has been associated with low remission rate.

\section{Conclusions}

CD200 and/or CD56 expression in ALL at diagnosis are poor prognostic indicators associated with biological aggressiveness and CD56 expression has been associated with low remission rate..

\section{References}

Abdulateef, N. A., Ismail, M. M., and Aljedani, H. (2014). Clinical significance of coexpression of aberrant antigens in acute leukemia: a retrospective cohort study in Makah Al Mukaramah, Saudi Arabia. Asian Pac J Cancer Prev, 15(1), 221-227.

Adnan Awad, S., Kamel, M. M., Ayoub, M. A., Kamel, A. M., Elnoshokaty, E. H., and El Hifnawi, N. (2016). Immunophenotypic
Characterization of Cytogenetic Subgroups in Egyptian Pediatric Patients With B-Cell Acute Lymphoblastic Leukemia. Clin Lymphoma Myeloma Leuk, 16 Suppl, S19S24 e11.

Alapat, D., Coviello-Malle, J., Owens, R., Qu, P., Barlogie, B., Shaughnessy, J. D., and Lorsbach, R. B. (2012). Diagnostic usefulness and prognostic impact of CD200 expression in lymphoid malignancies and plasma cell myeloma. Am J Clin Pathol, 137(1), 93-100.

Atfy M, E. H., Elshorbagy SE, Atteia HH (2015). CD200 Suppresses the Natural Killer Cells and Decreased its Activity in Acute Myeloid Leukemia Patients. J Leuk., 3(190).

Barclay, A. N., Wright, G. J., Brooke, G., and Brown, M. H. (2002). CD200 and membrane protein interactions in the control of myeloid cells. Trends Immunol, 2 ،(6)3 $.290-285$.

Borowitz, M. J., Shuster, J. J., Civin, C. I., Carroll, A. J., Look, A. T., Behm, F. G., . . . Crist, W. M. (1990). Prognostic significance of CD34 expression in childhood Bprecursor acute lymphocytic leukemia: a Pediatric Oncology Group study. J Clin Oncol, 8(8), 1389-1398.

Bryceson, Y. T., March, M. E., Ljunggren, H. G., and Long, E. O. (2006). Synergy among receptors on resting $\mathrm{NK}$ cells for the activation of natural cytotoxicity and cytokine secretion. Blood, 107(1), 159-166.

Coles, S. J., Wang, E. C., Man, S., Hills, R. K., Burnett, A. K., Tonks, A., and Darley, R. L. (2011). CD200 expression suppresses natural killer cell function and directly inhibits patient anti-tumor response in acute myeloid leukemia. Leukemia, 25(5), 792 799.

Cox, C. V., Diamanti, P., Hazell, M., and Blair, A. (2014). CD200 May be a Potential Target for Therapy in Standard Risk Childhood ALL. Blood, 124(21), 4787-478.

Dalmazzo, L. F., Jacomo, R .H., Marinato, A. F., Figueiredo-Pontes, L. L., Cunha, R. L., Garcia, A. B., . . Falcao, R. P. (2009). The presence of CD56/CD16 in T-cell acute lymphoblastic leukaemia correlates with the expression of cytotoxic molecules and is associated with worse response to treatment. Br J Haematol, 144(2), 223-229.

Elyamany, G., Fadalla, k., and Abdulaaly, A. A. (2013). Abnormal expression of CD79a, CD56 and CD7 in acute myeloid leukemia. Pathology Discovery, 1(1), 6.

Eren, R., Aslan, C., Yokus, O., Dogu, M. H., and Suyani, E. (2016). T-cell acute 
lymphoblastic leukemia with co-expression of CD56, CD34, CD117 and CD33: A case with poor prognosis. Mol Clin Oncol, 5(2), 331-332.

Farag, S. S., VanDeusen, J. B., Fehniger, T. A., and Caligiuri, M. A. (2003). Biology and clinical impact of human natural killer cells. Int J Hematol, 78(1), 7-17.

Fauriat, C., Just-Landi, S., Mallet, F., Arnoulet, C., Sainty, D., Olive, D., and Costello, R. T. (2007). Deficient expression of NCR in NK cells from acute myeloid leukemia: Evolution during leukemia treatment and impact of leukemia cells in NCRdull phenotype induction. Blood, 109(1), 323330.

Fischer, L., Gokbuget, N., Schwartz, S., Burmeister, T., Rieder, H., Bruggemann, M., . . . Thiel, E. (2009). CD56 expression in T-cell acute lymphoblastic leukemia is associated with non-thymic phenotype and resistance to induction therapy but no inferior survival after risk-adapted therapy. Haematologica-the Hematology Journal, 94(2), 224-229.

Gorczynski, R. M. (2001). Transplant tolerance modifying antibody to CD200 receptor, but not CD200, alters cytokine production profile from stimulated macrophages. Eur $J$ Immunol, 31(8), 2331-2337.

Gorczynski, R. M., Chen, Z., Hu, J., Kai, Y., and Lei, J. (2001). Evidence of a role for CD200 in regulation of immune rejection of leukaemic tumour cells in C57BL/6 mice. Clin Exp Immunol, 126(2), 220-229.

Gorczynski, R. M., Chen, Z., Lee, L., Yu, K., and $\mathrm{Hu}$, J. (2002). Anti-CD200R ameliorates collagen-induced arthritis in mice. Clin Immunol, 104(3), 256-264 .

Gorczynski, R. M., Lee, L., and Boudakov, I. (2005). Augmented induction of CD4+CD25+ Treg using monoclonal antibodies to CD200R. Transplantation, 79(4), 488-491.

Hashimoto, S., Toba, K., Aoki, S., Tsuchiyama, J., Tsukada, N., Takahashi, H., . . A Aizawa, Y .(2002) .Acute T-lymphoblastic leukemia relapsed with the character of myeloid/natural killer cell precursor phenotype: a case report. Leukemia Research, 26(2), 215-219.

Hoek, R. M., Ruuls, S. R., Murphy, C. A., Wright, G. J., Goddard, R., Zurawski, S. M., . . . Sedgwick, J. D. (2000). Downregulation of the macrophage lineage through interaction with OX2 (CD200). Science, 290(5497), 1768-1771.

Hu, W., Wang, X., Yang, R., Bi, L., Xie, Y., Zhang, Z., . . Wu, L .(2016) .Expression of
CD56 is a risk factor for acute lymphocytic leukemia with central nervous system involvement in adults. Hematology, 1-7.

Hussein, S., Gill, K. Z., Sireci, A. N., Colovai, A. I., Small, T., Emmons ‘F. N., ... Alobeid, B. (2011). Aberrant T-cell antigen expression in B lymphoblastic leukaemia. Br J Haematol, 155(4), 449-456.

Jenmalm, M. C., Cherwinski, H., Bowman, E. P., Phillips, J. H., and Sedgwick, J. D . .(2006)Regulation of myeloid cell function through the CD200 receptor. J Immunol, 176(1), 191-199.

McCaughan, G. W., Clark, M. J., Hurst, J., Grosveld, F., and Barclay, A. N. (1987). The gene for MRC OX-2 membrane glycoprotein is localized on human chromosome 3. Immunogenetics, 25(2), 133-135

Montero, I., Rios, E., Parody, R., PerezHurtado, J. M., Martin-Noya, A., and Rodriguez, J. M. (2003). CD56 in T-cell acute lymphoblastic leukaemia: a malignant transformation of an early myeloidlymphoid progenitor? Haematologica, 88(7), ELT26.

Paietta, E., Neuberg, D., Richards, S., Bennett, J. M., Han, L., Racevskis, J., . . . Eastern Cooperative Oncology, G. (2001). Rare adult acute lymphocytic leukemia with CD56 expression in the ECOG experience shows unexpected phenotypic and genotypic heterogeneity. Am J Hematol, 66(3), 189-196.

Pankratova, S., Bjornsdottir, H., Christensen, C., Zhang, L., Li, S., Dmytriyeva, O., . . . Berezin, V. (2016). Immunomodulator CD200 Promotes Neurotrophic Activity by Interacting with and Activating the Fibroblast Growth Factor Receptor. Mol Neurobiol, 53(1), 584-594.

Porwit, A., and Rajab, A. (2015). Flow cytometry immunophenotyping in integrated diagnostics of patients with newly diagnosed cytopenia: one tube 10color 14-antibody screening panel and 3tube extensive panel for detection of MDSrelated features. Int J Lab Hematol, 37 Suppl 1, 133-143.

Ravandi, F., Cortes, J., Estrov, Z., Thomas, D., Giles, F. J., Huh ،Y. O., . . Kantarjian, H. M. (2002a). CD56 expression predicts occurrence of CNS disease in acute lymphoblastic leukemia. Leuk Res, 26(7), 643-649.

Ravandi, F., Cortes, J., Estrov, Z., Thomas, D., Giles, F. J., Huh, Y. O., . . Kantarjian, H. M. (2002b). CD56 expression predicts occurrence of CNS disease in acute 
lymphoblastic leukemia. Leukemia Research, 26(7), 643-649.

Rygiel, T. P., Karnam, G., Goverse, G., van der Marel, A. P. J ‘.Greuter, M. J., van Schaarenburg, R. A., . . . Meyaard, L. (2012). CD200-CD200R signaling suppresses anti-tumor responses independently of CD200 expression on the tumor. Oncogene, 31(24), 2979-2988.

Seegmiller, A. C., Kroft ‘S. H., Karandikar, N. J., and McKenna, R. W. (2009). Characterization of immunophenotypic aberrancies in 200 cases of B acute lymphoblastic leukemia. Am J Clin Pathol, 132(6), 940-949.

Shannon K Oda1 , A. W. D., Nicolas M Garcia1,Xiaoxia Tan1 and Philip D Greenberg. (2016). Expression of a CD200targeted chimeric costimulatory receptor enhances $\mathrm{T}$ cell effector function and adoptive immunotherapy of disseminated leukemia. The Journal of Immunology, 196, 213-218.

Shibuya, A ‘.Nagayoshi, K., Nakamura, K., and Nakauchi, H. (1995). Lymphokine requirement for the generation of natural killer cells from CD34+ hematopoietic progenitor cells. Blood, 85(12), 3538-3546.

Suzuki, R., Murata, M., Kami, M., Ohtake, S., Asou, N., Kodera, Y., . . . Nakamura, S. (2003). Prognostic significance of
CD7(+)CD56(+) phenotype and chromosome 5 abnormalities for acute myeloid leukemia M0. International Journal of Hematology, 77(5), 482-489.

Thomas, X., Archimbaud, E '.Charrin, C., Magaud, J. P., and Fiere, D. (1995). CD34 expression is associated with major adverse prognostic factors in adult acute lymphoblastic leukemia. Leukemia, 9(2), 249-253.

Timothy, A., and Ahmed, A. (2016). Immunotherapy and Acute Lymphoblastic Leukemia. EC Cancer 2.3 141-147.

Walker, D. G., and Lue, L. F. (2013). Understanding the neurobiology of CD200 and the CD200 receptor: a therapeutic target for controlling inflammation in human brains? Future Neurol, 8(3).

Wright, G. J., Jones, M., Puklavec, M. J., Brown, M. H., and Barclay, A. N. (2001). The unusual distribution of the neuronal/lymphoid cell surface CD200 (OX2) glycoprotein is conserved in humans. Immunology, 102(2), 173-179.

Xiong, Z., Ampudia-Mesias, E ‘.Shaver, R., Horbinski, C. M., Moertel, C. L., and Olin, M. R. (2016). Tumor-derived vaccines containing CD200 inhibit immune activation: implications for immunotherapy. Immunotherapy, 8(9), 1059-1071. 


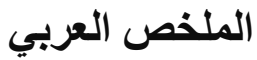

عنوان البحث: المدلول الأكلينيكى ل CD200 و CD56 فى مرضى سرطان الام الليمفاوى الحاد

صلاح الثحات عارف1، قدري عبد القادر البكري، عماد الدين عزمي حسن3، لبنى سامى إبراهيم²

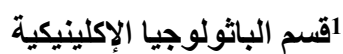

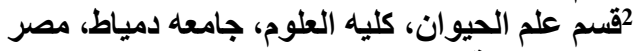

3 قسم الباطنة ، كليه الطب، جامعه المنصورة ، مصرط

إن سرطان الام الليمفاوي الحاد يعد من اكثر أنواع السرطانات انتثارا وقد أصبح الاتجاه في معظم الاراسات

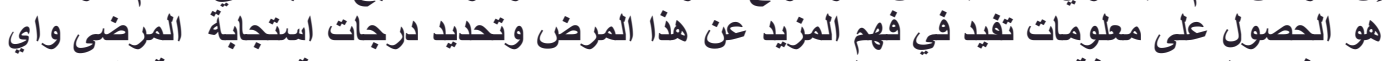

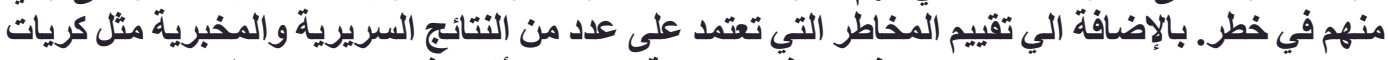

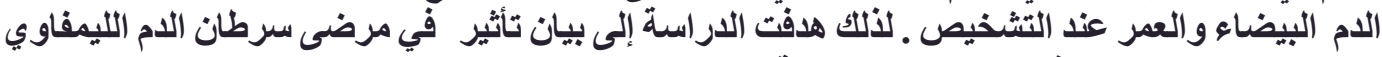

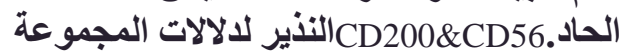

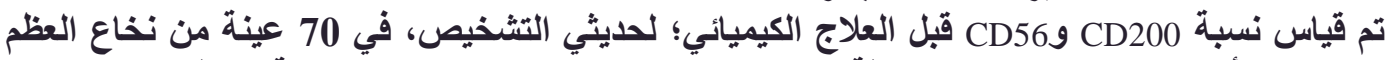

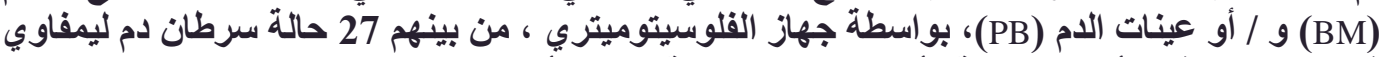

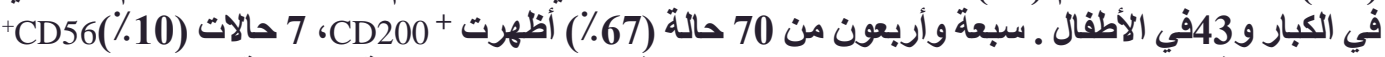

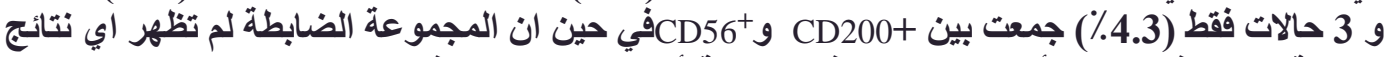

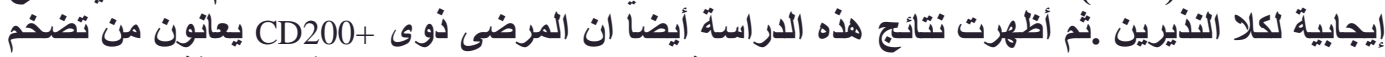

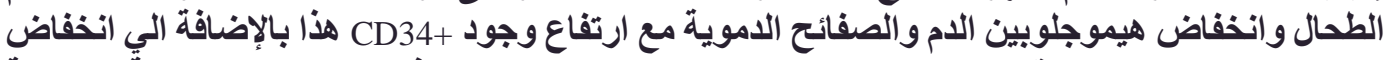

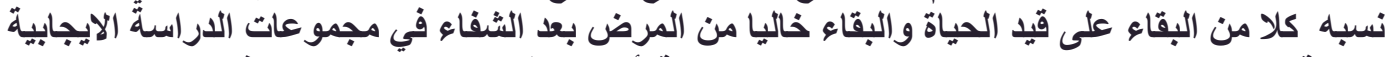

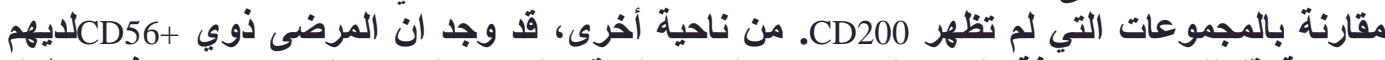

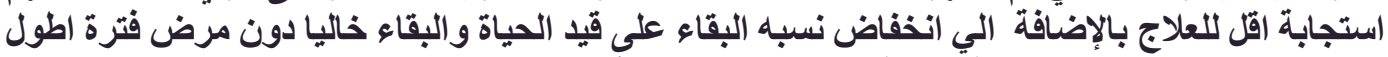

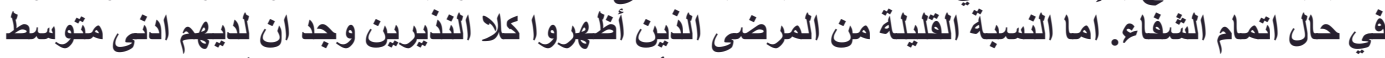

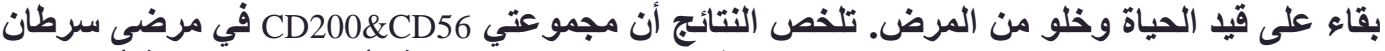

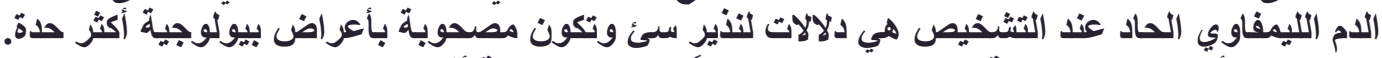
علاوة على أن دليل المجموعة CD56. يكون مصحوبًا بمعدل استجابة أقل للعلاج. 